\title{
Teaching Junior High School Chemistry During the COVID-19 Community Quarantine Season: Lessons, Challenges, And Opportunities
}

\author{
Ryan Villafuerte Lansangan \\ University of Santo Tomas Junior High School, España, Manila, Philippines \\ *Author to whom correspondence should be addressed; email: rvlansangan@ust.edu.ph
}

\begin{abstract}
This paper reports an autoethnographic study of a junior high school chemistry teacher's field experience in remote chemistry teaching during the Enhanced Community Quarantine (ECQ) brought by COVID-19 in the Philippines. The teaching of chemistry for Junior High School in an online setting is possible but has challenges as well. Rooted from the pedagogic data and selfnarration, this work examined the insights on the lessons, challenges and opportunities associated in teaching chemistry in basic education in an online mode. The researcher's online chemistry teaching experience can be recapped in an acronym "REACH OUT". Reinventing the wheel; Exploring the possibilities; Aligning to core essentials; Creating a learning routine; Hooking students online meaningfully; Offering consistent means of communication; Using authentic and reflective assessments; and Trusting the process. This paper, a pioneering of its kind, offers implications that can be embraced as we move into the new normal of having optimized online teaching experience and in shaping an undisruptive education that is responsive to crisis like the COVID-19 pandemic.
\end{abstract}

Keywords: remote teaching; online learning; chemistry education research; autoethnographic study

\section{INTRODUCTION}

The World Health Organization declared COVID-19 as a pandemic on March 11, 2019 and rapidly became a massive international concern. As a response to this global health crisis, governments in numerous countries have introduced series of steps aiming to curb its effects. In the Philippines, when the localized transmission of the said virus was recorded, the government regarded it as a risk to national security (Nicomedes, et al., 2020) forcing it to implement the Enhanced Community Quarantine (ECQ) in areas where there are COVID-19 cases on March 16, 2020 and declared a state of calamity the following day. Since it was followed by a spike in new confirmed cases and local transmission, it was extended to April 30, 2020, then to May 15, and to May 30 
looming for the flattening of the curve. At the time of this writing, the Department of Health reported 13,221 active cases, majority of which in the National Capital Region (NCR) (54\%), 2,932 recoveries and 842 deaths (DOH, COVID-19 Bulletin No, 67). Spatial distancing is one of the strongly promoted practices by creating and keeping safe distances among individuals, limiting free movements, placing people in quarantine, and closing businesses and services that are not considered essential (Abel \& McQueen, 2020; Wilder-Smith \& Freedman, 2020; Miller, 2020). This practice resulted to temporary closures of institutions and establishments where there are mass gatherings. The environment becomes more controlled and restricted each day with the onslaught of the virus. These brought new scenarios and modified habits to many people because of the great changes in the social interaction and organization where they are used. The countries most affected by the virus spreading are facing an unprecedented health crisis, whose effects impact the economy and social structures for a long time (Favale, et al., 2020). Education has not been immune to this (Murphy, 2020). It has cause various levels of distuptions in education globally because of school closures in an attempt to prevent the spread of the disease, impacting over 1.5 billion students as reported by UNESCO.

As a consequence, learning institutions at all stages of schooling have to adapt their educational practices and provisions to quickly shifting circumstances under a state of ongoing uncertainty. Depending upon the school calendar, all on-going activities that were immediately cancelled need to recalibrate its institutional plans to ensure workforce and assure proactive measures amidst the pandemic. To ensure adherence to stakeholders, policies were created such as the provision of alternative delivery modes and quarantine protocols (CHED, 2020; DepEd, 2020). The most significant challenge in the sector is the continuing education especially to those schools that are still in the middle of the academic year as there is no precedent to serve as guide in the immediate shift of direction. As days passed by during the pandemic, there has been a growing reliance on the use of technology to learn, live, and stay connected (Goldschmidt, 2020). It highlighted its major role in supporting remote working, e-teaching, and online collaboration. The tsunami of online learning has occurred. Many schools ventured into offering online or virtual learning for students as a means to continue teaching and learning (CDCP, 2020). Teachers who were reluctant to teach online had a little choice but to embrace this mode. The said new normal posit worries to teachers since they have not been trained for emergency online teaching (Talidong \& Toquero, 2020). The digital divide is more apparent than ever (Guernsey, Ishmael, \& Prescott, 2020). The so-called generation $\mathrm{Z}$ of learners is ready for it but teachers and the methods are bit behind. Clamors from educators all over the world are hoping that new models of undisruptive education will emerge in the unfolding pandemic. This shift further signified that internet access is really now a necessity and not a commodity. However, in the latest data of Speedtest Global Index Study, Philippines ranks $121^{\text {st }}$ among the 139 countries, with an average mobile internet download speed of $12.09 \mathrm{Mbps}$ far below the global average of $26.12 \mathrm{Mbps}$. More significant for consideration, it cannot be denied that there still have a disproportionate number of children who don't have access on it.

While the spread of the virus has resulted in far-reaching consequences, the closure of schools led to the exposition of innovative methods of delivering education ensuring that the learners continue to study through the different methods of modality (Sandhu \& de Wolf, 2020). Talidong \& Toquero (2020) reported in their work that Filipino teachers practice virtual learning and communicate to professional community during the quarantine period. In fact, the pandemic has introduced a lot of opportunities for novel practices in the education field on how to maximize the online platforms in the continuity of educative episodes. Schools have devised ways of transfiguring their cancelled activities and teachers explored different online platforms by participating to webinars and interact virtually while learning from practices from others available all over the world. One common trend and extraordinary measures of most educational 
institutions is to embrace "emergency eLearning" protocols, marking the rapid transition of faceto-face classes to online learning systems (Murphy, 2020). This transition further gave birth to many challenges that teachers face in their work. For instance, not all learning institutions have online learning management system that will greatly contribute to learning setbacks (Binkley, 2020). While schools with subscription to technology-based instructions can prevent students from falling behind academically, its implementation can still be delivered poorly for some reasons (Morgan, 2015). Some factors may include lack of well-established structure in facilitating remote and virtual teaching and learning environment; capacity of teachers to navigate the online platforms; and the varying scenarios concerning the internet connectivity of both teachers and learners. But still, in times like this, teachers have to quickly readjust their curriculum and find ways to provide education to students (Miller, 2014). Indeed, teachers are not immune to the vulnerabilities due to COVID-19.

In response to enhance community quarantine (ECQ), the school where the author is affiliated, proceeded to employ emergency remote teaching for the remaining days of the school year. To this end, this undertaking would like to share the actual personal experiences of implementing emergency remote chemistry teaching and highlight the lessons, challenges, and opportunities that can be embraced as we move into the new normal of having optimized online teaching experience and in shaping an undisruptive education that is responsive to crisis like this pandemic. The reflections and insights from these experiences envisions to benefit educators in restructuring their practices thereby mitigating the challenges that may hinder effective delivery of remote education. This adheres to UNESCO's (2020) pronouncement that "the goal is to identify and share the best innovations to keep children learning during the pandemic, and to help lay foundations for more inclusive and equitable approaches to education when the crisis subsides."

Online Learning, the Way to Go. Gemin and Pape (2016) defined online learning as teacher-led education through the Internet, with teachers and students separated geographically, using webbased delivery system with software that provides a structured learning environment. Two modes of online learning are practiced in the field, the asynchronous and the synchronous online teaching. Asynchronous on-line instruction involves dissemination of materials on chosen platforms, which may include pre-recorded flipped sessions, use of emails or blog posts while synchronous on-line teaching involve real-time live sessions delivered through live video conferencing (Moorhouse, 2020). Depending upon the situations, each approach can be used independently or as a mixture. Well-planned online learning experiences are meaningfully different from courses offered on online in response to a crisis or disaster. The most cited reasons in venturing to online platforms is its potential to provide more access to content and instruction at any time and place, especially for students who choose not to subscribe to traditional academic settings (Means, et al., 2010).

In emergency remote teaching, the objective is to quickly adapt to teaching online due to external force and in order to achieve normalization (Hodges, et al., 2020). Because of the situation such as the pandemic, asynchronous and synchronous on-line teaching requires new and extended skill sets since teachers lack experiences on it being used to face-to-face classroom setting (Peachey, 2017). Doucet, et al. (2020) acknowledged the technological cultures among teachers and the access to technology as one of the challenges. But crises like this drive innovations by making the most out of the available tools and skills. These innovations are hindered by several factors both from the students and the teachers but creativity is indeed the cornerstone in approaching emergency remote education.

In the normal setting, the rapid growth of online education at the K-12 levels in recent years calls for an opportunity to explore issues that influence the academic experiences of students (KumiYeboah, et al., 2018). This growth is associated to several factors such as availability of educational technology at the K-12 level (Curtis \& Werth, 2015); capacity to facilitate $21^{\text {st }}$ century skills (Rice, 
2012); personalized learning and individualized mentoring for students (Cavanaugh, et al., 2013); and potential benefits to diverse groups of students (Spitler, 2013). Driver (2018) reported that online students lament how their learning experiences lack interpersonal connections in the mediated online platform in agreement with what Reedy (2019) identified as lack of sense of community. Having these perceptions among learners serve as vital springboard for teachers to strategize an engaging and motivating online learning experience. Cited from the work of Kaufmann \& Vallade (2020), there is a field known as instructional communication that centers on the study of the communicative factors in the teaching-learning process. Chatham-Carpenter (2017) identified the need for researchers in the field to explore how learning transpires through technology and how communication takes place as a result of instructional virtual connections between the teacher and the learner. Kaufman \& Buckner (2019) described teachers' communication behaviors to be cognizant, strategic, and intentional to arrive for an effective online learning communication. Research involving instructional communications is underpinned by the theory known as rhetorical and relational goals theory to examine the impact of communication on learning outcomes. Kaufmann \& Frisby (2017) defined rhetorical goals as those learning tasks or outcomes being communicated to students to maximize engagement, which is more concerned with cognitive and behavioral assessment while relational goals dwell on building connections based on liking, perceived supportiveness, caring and connectedness, in conjunction with what Finn \& Schrodt (2012) identified as rapport, climate, connection, and affect. Mottet, et all. (2006) affirmed that even the two goals have independence, it may not always be the case. Incompetence or failing to achieve one of these goals may result to the same effect of the other goal. Similarly, addressing both goals brings positive perception among learners (Myers \& Goodboy, 2014). Conrad \& Weber (2015) thereby cautioned online teachers that the mere inclusion of learning activities where students interact is not always enough. Thus, Dunlap \& Lowenthal (2014) affirms the necessity to create a sense of presence between and among teachers and students.

In the era of internet, as cited from the works of Shearer et al. (2020), the Community of Inquiry (CoI) model by Garrison et al. (1999) depicts the combination of essential constructs that can help assure a good online experience. These three constructs are: (1) the cognitive presence, which involves construction of knowledge by the community of learners through sustained reflection and discourse; (2) the social presence, which gives a sense of being in a virtual environment while projecting personalities; and (3) the teaching presence, which describes what the teacher facilitates by modelling behaviors to navigate the learning experiences of learners within a structured online community building an educationally worthwhile outcomes. These three presences are overlapped in a Venn diagram with the core representing the educational experience. From the teachers' perspective, Shearer, et al. (2020) identified three emerging areas that describes teachers experiences in online teaching. First is the use of eclectic pedagogical approach that venture into the idea that no single pedagogical practice can surmise the needs of an effective online learning experience. It is further interpreted based on the teachers emerging personalized or adaptive, transformative, collaborative, constructive, and connected learning experiences. Second, the need for a shift from content delivery to providing an interactive and engaging learning experience that can be brought by streamlining subject contents focusing on amplified and in-depth exploration to define the meaning of the learning. Third, the inclusion of psychological consideration by adding emotional design and students brief onboarding experience by acclimating them to online culture while boosting their engagement.

In the onslaught of COVID-19, the International Society for Technology in Education (ISTE, 2019), a reputable and leading education news organization published suggestions on how to carry out remote learning during the pandemic. These suggestions included ensuring equity, clear communications of expectations, provision of student-centered learning and response to 


\section{Teaching Junior High School Chemistry During the COVID-19 Community...}

emotional toll a pandemic can bring to both teachers and learners (ISTE, 2019). Similarly, the Foundation for Information Technology Education and Development, (FITED, 2020) released a teacher's guide for remote learning during school closures and beyond. FITED identified three key areas to be considered: the content of the curriculum, the learning profile of the students and the learning design and implementation. Using the publications of these notable organizations can help mitigate the challenges that educators might face in the remote teaching mode.

Doucet, et al. (2020) affirmed that the pedagogical choices through distance learning lens is guided with the notion that there is no one-size-fits all. There is a great variety of subjects with varying needs with some can be easily translated synchronously and some asynchronously. Others require practical components such as in physical education and technology and livelihood education classes or specialized equipment such as science experiments that cannot be easily replicated in the virtual mode. Teachers must really plan the suitability of realistic approach that will allow continuity of learning without sacrificing the competencies and the nature of the subject.

Challenges in Online Chemistry Teaching. Childers and Jones (2017) identified three factors that contribute to a remote learning environment in science. These are the science learning drive, which deals with competence and performance; the environmental presence, which has something to do with the control of the remote technology; and the inner realism of how real is the remote activity. Argles (2017) pointed blended static and dynamic support in a mix approach enable most students to succeed in a science online learning in consideration of the idea that different distance student's flourish via different learning styles.

As an applied science, chemistry is regarded as a professional jargon used to express complex natural phenomena through the interplay of representations, from chemical names, formulas, equations, and illustrations (Markic \& Childs, 2016). Typical high school chemistry instruction and assessment involves quantitative problem solving and symbolic manipulations assuming the students learn core concepts through these fashions. However, all too often, assessments of procedural knowledge suggest mastery but assessments of associated concepts revealed many students learn the procedures without understanding the core principles (Taskin, et al., 2014). Chandra \& Sharma (2018) identified alternative platforms of delivering chemistry lessons such as through satellite, internet and mobile telephony, and their composite applications can ensure maximum academic throughput. In comparing the chemistry teaching and learning scenarios between face-to-face and remote platforms, several constructs were explored. Weaver, et. al. (2009) unraveled how the mode of communications is affected by the format; Gulacar, et al. (2013) used the performance in examinations as point of comparison; Faulconer, et al., (2018) pointed the passing, withdrawal rates and grade distribution; and Nennig, et al. (2019) suggested discussion model that make use of metacognition. In terms of online delivery of chemistry lessons, flipped classroom continues to catch a lot of attention (Fautch, 2015). It was introduced in chemistry through the works of Bergmann and Sams (2012) and Arnaud (2013) with the majority of the empirical observations in general chemistry in high school.

In the work of Fautch (2015) potential problems in its execution were identified such as inability of students to immediately ask questions, students' inhibition to collaborate and inability of the instructor to know if each student viewed each lecture in its entirety. In addition, McCollum, et al. (2019) identified the barriers students encounter in an international online collaborative activity in chemistry that include those that are out of control by the instructors such as Wi-Fi bandwidth, and non-responsive audience and those that are intentional learning experiences such as chemistry language, content, and scheduling. Parallel to the work done by Eckert, et al. (2009), Chandra \& Sharma (2018) identified three major challenges in deploying chemistry teaching online, these are selecting a suitable learning resource for the target group, presenting essentially demonstration 
experiments and difficulty in extraction students' communication of their learning, application and understanding of chemistry.

\section{METHODS}

Research Design. The current study employed a qualitative inquiry using method known as autoethnography, which according to Adams and Hermann (2020), is comprised of three interrelated components: "auto" referring to selfhood, subjectivity, and personal experience; "graphy" to describe, interpret and represent; and "ethno" for identities of a group or culture. It emphasizes researcher's subjectivity and reflexive self-observation contrary to a generalizable description of objective phenomena (Bochner and Ellis, 2016) adapting a data-driven approach to reflection (Walsh and Mann, 2015) as it incorporates ethnographic data and develop a self-narrative through multiple sources (Yung, 2020). Hayler (2011) affirmed this method of inquiry that provides windows for teacher educators to gain insights into their work and identity by examining their own lived experiences and what Farrell (2015) pointed as a way to account to what has shaped the teaching practice and how it affected by the lived experience.

The trustworthiness of how data will be interpreted was constantly negotiated through engaging in critical dialogues with other teacher educators which is what Bochner and Ellis (2016) regarded as a way of contextualizing the narrative alongside others and stimulated contrary perspectives for more rigorous analysis.

Data Sources. The data sources revolved on what Allwright and Hanks (2009) refer to as "pedagogic data" or those data arising naturally as a result of the teaching and learning that comes from students work during the course of enhanced community quarantine (March 16 to May 30, 2020). In addition, data were also drawn from feed backs from colleagues and students, field notes, reflections of students, observations and online group discussions with teachers and parents of the grade level.

\section{RESULTS AND DISCUSSION}

Self-Portrait in Context. I am a junior high school science teacher since 2009 from a catholic university in Metro Manila. For the past 11 years, I'm handling chemistry classes and have experienced being a subject chairman, club moderator and member of various school committees. This school year 2019-2020, I am handling four Grade 9 chemistry classes following a disciplinal approach that our school started in 2018. In addition, I am serving as the grade level head teacher (for three years now) with the task of maintaining the discipline of students in the grade level and providing a communication bridge for teachers to all matters concerning the level. Regarding my routine as a chemistry subject teacher, I teach chemistry for 75 minutes per class and facilitate laboratory classes once a week. Our school calendar begins on the month of August and ends on May.

When Mayor "Isko Moreno" Domagoso announced the suspension of classes in the City of Manila on March 9 to 15, 2020 as a preventive measure due to corona virus threat (Domagoso, 2020), our basic education unit is currently on its first day (March 9) of administering the third quarterly test. During that period of time, WHO characterized the situation as pandemic, where there were 125,048 confirmed cases in 118 countries around the world (WHO, 2020). In response to the continuity for teaching and learning amidst the mandatory quarantine and class suspensions, our school released a memorandum advising the teachers to maximize the utilization of the UST Cloud Campus to continue instructional delivery (UST Advisory, March 20, 2020). Cloud Campus is the Blackboard Learning Management System (LMS) of the university that has been in operation since 2002. It is formerly known as e-LeAP and renamed Cloud Campus in 2018 (UST Website News 
and Events, 2020). The memo further directed teachers to provide review materials using the platform observing assigned schedule per subject in consideration of easing the burden of the suspension but not overwhelming the learners.

Our eLearning specialist began offering virtual technical assistance to teachers on how to navigate the different features of the said platform. Informational materials were sent to serve as guide for teachers in deploying online materials for students use (UST EdTech Center Facebook page, March 9, 2020). Recalling, my last training about this were just on July 30, 2015 (Creating Online Courses) and on March 7, 2017 (Cloud-Based Technologies for Teaching and Learning). From then on, I've been using the Cloud Campus but mostly in deploying slides, posting announcements, providing supplementary materials, and giving few formative assessments. Considering these little engagements, truly, I haven't maximized the other features of the LMS due to time constraint. When the government declared Code Red Sub-level 2, Metro Manila was placed under community quarantine and classes were further suspended until April 12, 2020 (Lopez, 2020). In view of this, our university suspended the online instructional engagements of faculty in order for the students and teachers to attend to personal and family concerns and offer time to design, curate and create online instructional materials good for the remaining days of the school year. We were allowed to go to school to get some personal things and instructional materials for one hour following the protocols stipulated in the collective institutional guidelines on COVID-19 set by the university. At the same time, the university started to facilitate the deployment of survey for the health status of students and their internet connectivity that may be of great help for teachers in preparing for the online and intervention classes. In our basic education unit, we deployed a local survey to gather data about the online connectivity of the students (Rodriguez, 2020). From the $71.58 \%$ turn outs, we obtained their internet connectivity profile. In terms of current location, $81.2 \%$ currently resides in the NCR while $18.8 \%$ in the province. Laptop $(61 \%)$ and cellular phones $(60.5 \%)$ are the most commonly used gadgets, with $34 \%$ on tablet and $18.8 \%$ on desktop. Majority of them $(95.9 \%)$ usually do their Cloud Campus activities at home with only $75.6 \%$ having a stable internet connection. We used this profile as one of the factors to be considered in planning our online instructional activities.

Through the Cloud Campus Faculty Handbook, I got the opportunity to review the different features of our LMS especially on how to do Blackboard (BB) Collaborate, a virtual classroom and online collaboration platform. From time to time, I had a constant online communication to our eLearning specialist, on areas that I am not familiar with. Recalling this journey, I got to realize the importance of taking seriously the previous professional developments given to teachers in the forms of trainings and workshops about technology integration in the classroom. There started my journey in doing emergency remote chemistry teaching.

The Take Off. Streamlining the content of our lessons was the first step initiated by our academic leaders by instructing us to focus mainly on the essential competencies. During that time, our chemistry lessons for the fourth quarter are the Variety of Carbon Compounds (S9MT-IIg-17), Biomolecules (S10MT-IVc-d-22) and Gas Laws (S10MT-IVa-b-21) based on our restructured curriculum map. My colleagues in the group decided to cover first the lessons on gas laws since our students have already took their lessons in variations in their mathematics class. We find that the patterns in using the required formula would enable the learners to more or less have an initial procedural knowledge of the content and conceptual knowledge follows in the synchronous online teaching. Since the lesson is somewhat mathematical, the reinforcement of the two is what Ngu, et al. (2016) cited a representation of essential components of mathematical proficiency.

Having such arrangement would give us more time in planning for the remote teaching of organic chemistry with the notion that materials need to be developed carefully because of the unusual language of the lesson. Organic chemistry has its own representational language and as with any 
language, any barrier with the language makes it difficult to understand (Visser \& Flynn, 2018). Its technical nature and specialized vocabulary often bring struggles to learners (Galloway, et al., 2017).

In my capacity as the level head teacher, I prepared a weekly schedule of the topics covered in all subjects using publication material based on the matrix released by the office. Online learning activity each day can be synchronous and asynchronous or a mixture of two. Through this, students and teachers are guided and at the same time learners are not overwhelmed with the list of tasks ahead of them. From time to time, I communicate to teachers regarding the details of the task, time for synchronous teaching, and some changes in the instructions along the way. I also deployed an online survey to students regarding their most preferred time in participating to synchronous learning.

Creating Communication Platform. I find communication very important during this emergency online instruction. As Doucet, et al. (2020) emphasized that during this emergency pandemic, the school becomes the center of communication for the community ensuring that the stakeholders are getting the information and instructions. To assure that all our plans and announcements are cascaded well to the concerned recipients, I maximized the use of different means of communications. I have group chats for the teachers, for the class leaders, for my advisees and for the parents where I post my announcements concerning the subjects. Ironically, in this time of social distancing, social media removed the barriers of skepticism and challenges by bringing us closer. Wiederhold (2020) affirmed that this COVID-19 crisis has seemingly accelerated our use of technology and social media to communicate with others and in ways that could be potentially beneficial. Through this, I can see on the bird's eye view as to whether everyone is updated and informed and an easy way of getting feedbacks and concerns from them. Especially to most parents who are not trained in acting as pseudo-teachers to their children in a remote learning, a provision of open communication for them will greatly help in mitigating the challenges that may arise as they supervise their children. This gives us an idea that a proper orientation to parents can be done prior to launching the remote classes. Kong (2018) is of the idea that schools can enhance parent's pedagogical understanding of e-learning and address parental concerns through school-parent collaboration and peer support among parents.

In terms of my chemistry instruction, though our LMS has a feature for posting announcement, I still created Facebook groups per section since majority of them are social media users. I maximized these groups especially in posting materials and screenshots of announcements that I assumed can be readily viewed and will give immediate notifications for students. Individualized communication though private messages in social media has also been maximized in accommodating students, teachers and parents' concern. I communicated with students regarding the progress on their works and address some misunderstanding about our lessons. I built communication with my colleagues with regards to policies of the school and exchange ideas about our practices in the online teaching. My constant communication with the parents provided proactive measures to lessen some confusions and barriers in the hand-in-hand responsibilities in guiding their children as they acted as pseudo-teachers while online engagements are ongoing.

Creating a Learning Structure. I familiarize myself in navigating the Cloud Campus, especially the Blackboard collaborate with the constant communication to our eLearning specialist. Prior to actual synchronous teaching, I had my rehearsals and proactively identified the possible troubleshooting measures that I may encounter while teaching online. Just like any other platforms, the Blackboard collaborate has video and audio streaming, live chatting, screen sharing, viewing of attendees, muting or disabling participants and recording and sharing sessions. It is important as an online teacher, I know how to operate the platform specifically the features dealing 
with interaction to students, considering the privacy of the learners and other technical aspects that may affect the online learning episodes.

Days before the actual session, I usually give the slides and supplementary videos before the synchronous engagement. Pre-lecture resources can reduce in-lecture cognitive load and diminish differences in achievement between students with prior knowledge of chemistry compared to students lacking this prior knowledge (Seery \& Donnelly, 2012).

I took into consideration the kind of learning structure that I will use for optimum chemistry learning. With the language that chemistry has, I devised several strategies on how to communicate it to students in their own pace. I prepare the content of the slides into chunks so students' conceptual understanding of a particular chemistry concept is confined and focused. Munyofu, et al. (2007) supports this idea as a way of reducing cognitive load present in an animated instructional environment. In the problem solving, like in gas laws, I present detailed solutions to the samples and the corresponding practical applications of the law. Whenever there are chemical structures in the slide, I played with different graphic visuals that will help communicate the meaning to the students. From time to time, I put topical and essential questions to lead the students into selfreflection and regulation. As compared to the slides that I use in face-to-face instruction, I find the "conversational" nature of the content to be more suitable for asynchronous online learning. What I meant by conversational here is the use of the material in a way that you are reimagining that you are talking to them. The challenge here is the way I communicate the macro, micro and sub-micro nature of the content, which requires an introspection of what chemistry tries to convey in the lesson. Lansangan, Orleans \& Camacho (2018) suggest that chemistry teaching should employ these levels of representations in varying levels. Though the challenge here is whether the students are really reading and understanding the content on their own space and time.

In my first attempt to engage in real time synchronous teaching, I join the session minutes before the announced time of the session. Since materials were already provided to them in the LMS, I focus my actual online teaching in emphasizing concepts and soliciting clarifications from the students. Almost $70 \%$ of my students attended the virtual class. For the benefit of those who were not able to attend, the session was recorded and the link was provided in the Cloud Campus and different communication platforms. During the actual session, some barriers that I experienced range from technical like internet connectivity issues, navigating the Blackboard in drawing some chemical structures and illustrations, and some disruptions brought by noise whenever some students recite, to socio-emotional such as inhibition of some students in recitation and engagement. Sadulski (2020) acknowledges these observations as challenges among K-12 students transitioning to online learning. My on-the-spot troubleshooting here includes using the emoticons in the chat to generate participation, raising questions in the chat box, maximizing the use of private messages to provide individual feedback, and having fillers from time to time that I termed "commercial". Indeed, introducing a learning structure in the online platform would help students be focused and directed to the expected learning experiences that they encounter in a virtual way.

Designing Contextualized Online Materials. I find contextualization effective in engaging students during the entire online teaching experience. For instance, I started teaching about the properties of gases by sharing news about the air quality in Metro Manila during the quarantine period (CNN Philippines, 2020) and shared how environmentalist monitor air quality. I introduced functional groups in organic chemistry by presenting the recipe of kare-kare, a famous Filipino stew, and all the ingredients of it with the corresponding organic compounds and structures that can be found in them. Integrated here is role of having a healthy lifestyle on the choice of foods that they eat especially during the pandemic. Gill, et al. (2020) supports this practice on instructional messages that heighten the personal relevance and challenge to prior beliefs produced 
conceptual change. These instances offered an opportunity for my students to share their personal experiences like the foods that they ate in lunch, which is right before our online discussion. Research in chemistry education demonstrates that authentic and context-based instructions helps students make connections and see how the learning of chemistry relevant to them (Davenport, et al., 2018). Research on science learning adheres to this notion that learning benefit results from contextualized knowledge being more readily accessible and more likely to transfer new situations (Bransford, et al., 2005).

Exploring Authentic and Reflective Assessments. Though the Cloud Campus is very efficient in making programmable assessments such as essay, fill in the blank, multiple choice, matching type, and true-or-false questions, I still find assessment challenging in terms of measuring the expected learning outcomes. In fact, majority of my students complied and got excellent marks in all the learning activities. Only few got low scores, which I communicated individually to solicit some feedbacks like their misconceptions and learning difficulties. Based on my interaction with my colleagues and friends, they raise points such as the poor internet connectivity that may hamper students' momenta; the unreliability of the results since students have access to notes and information is simply a click away from them; assistance of other people at home while taking the test; and the possibility of online cheating. These observations were consistent to what Doucet, et al. (2020) identified regarding the practices of teachers on assessment learning in time of a pandemic. Nonetheless, these reasons may or may not be applicable to my students, I started contemplating how will I make a developmentally-appropriate assessment strategy so that I can communicate to them what chemistry is trying to convey in the lessons that we tackled.

Being the subject chair, I suggested the use of authentic assessment in the form of cooking that utilize organic materials and making infographics out of it in a digital format. Good to note, the Cloud Campus provided an efficient and effective way of incorporating rubrics in evaluating the students' output that are then graded based on infographic content, presentation, work quality, sourcing, and conceptual integration. To maximize monitoring of progress in the completion of the task, the students were invited to communicate to me individually through social media private chats for the purpose of collaboration and critiquing of their ongoing performance task. According to Koedinger and Aleven (2016), as students work independently at their own pace, teachers would be able to work with individual students, which have been proven to be effective in research using online systems that provide customized feedback. Through this, it was realized that in times like this, at their age, what is important are the learning experiences the students can encounter in online exposure instead of focusing merely on the content. It is also equally important to remind the students of the values in taking any forms of assessment that it is for their own good and development.

Collaborating and Seeking Feedbacks. Throughout the online learning experience, collaboration was found to be one of the significant ways to mitigate some personal, instructional, and technical challenges. This is in agreement with the report by Fishman et al. (2014) who revealed that in an online science teacher community platform where teachers can discuss teaching strategies, share resources, and connect with each other showed significant association with their self-reported shifts in practice and brings positive gains in student achievement.

The consistent communications and collaborations among the students, parents, and teachers employed in this work built a knowledge-sharing community and realized that everyone's shared roles make the adjustment of the educative process smoother towards an undisruptive learning. Learning from the experiences of others and sharing practices further strengthened the mutual desires of the teachers to deliver quality education by maximizing the available resources in times of emergency remote teaching. Darling-Hammond et al. (2017) opined that professional development correlates to student gains when it was on-going, connected to practice, focused on 
specific academic content, linked to school initiatives and more so, collaborative. Opportunity that can arise from this experience would be the introduction of localized professional development community among teachers in school where they can use the platform in sharing effective practices and solutions to instructional problems that they encounter in the actual instructional delivery. This can lead to what Lave and Wenger, as cited from Frumin (2018), that a community of practice is enacted by groups of people over time in shared practices where they interact, learn together, and develop a sense of mutual commitment.

\section{IMPLICATIONS AND INSIGHTS}

This autoethnographic research provides windows to educators by examining their roles in continuing their duties amidst the emergency situations such as the pandemic brought by COVID19. Since there is no precedent as to what framework should govern the practices in teaching, this has magnified and proven that the cornerstone in responding to the demands of uncertainty is creativity. Reimagining teachers' identity in times like this through the lived experiences in their practice calls for recalibrating not only one's expertise but a deeper sense of understanding of how to make the subject matter relevant to students. Truly, as different approaches in online teaching mushroomed from wide array of studies and literature, every practice boil down to the capacity of the teachers to negotiate their roles from the demands of changing time encompassing both personal and professional responsibilities. It is therefore equally relevant to realize that sharing these experiences may build a vibrant goal that while we wait for the COVID-19's flattening of the curve, teachers must remain intact in going back to the core of the teaching profession, and that is, avoiding the flattening of the learning curve. As Doka (2020) opined, the effects of this disaster is no different in that it can both destroy preexisting communities while also striving to build a sense of community and meaning.

To this end, the following points are raised from the lessons, challenges, and opportunities that can be derived from the examined lived experiences of the researcher. These points revolve around the idea that this online chemistry teaching experience can be recapped into "REACH OUT". Reinventing the wheel; Exploring the possibilities; Aligning to core essentials; Creating a learning routine; Hooking students online meaningfully; Offering consistent means of communication, Using authentic and reflective assessments; and Trusting the process.

1. Reinventing the wheel by being creative in optimizing the most of what we have without compromising the students' learning experiences.

2. Exploring the possibilities by getting out from the comfort zone and being open-minded to changes through continuous professional learning of the tools that can make the instructional duties relevant and focused.

3. Aligning the teaching to the essential competencies by being fixated to what is mandated in the curriculum but allows degree of possible articulation and integration.

4. Creating a learning routine by making the learners comfortable and guided into a new mode of flexible instructional delivery.

5. Hooking students by using engagement as the key to keep them in the process of meaning making.

6. Offering consistent means of communication to stakeholders to mitigate barriers and challenges in the demands of a sudden shift of teaching and learning modality and by conveying the idea that everyone is part of the educative process.

7. Using authentic and reflective assessments for students to find meaning and personal relevance to what they learn and do while learning independently.

8. Trusting the process that from pure intentions of teaching the students, it will lead them to the path of lifelong learning. 


\section{REFERENCES}

Abel T, McQueen D, The COVID-19 pandemic calls for spatial distancing and social closeness: not for social distancing! Int J Public Health. 2020 Apr; 65(3):231. https://doi.org/10.1007/s00038-020-01366-7.

Adams TE, Herrmann AF, Expanding our autoethnographic future. J Autoethnography. 2020 1:18. https://doi.org/10.1525/joae.2020.1.1.1.

Allwright D, Hanks J, The developing language learner. Basingstoke: Palgrave Macmillan; 2009.

Argles T, Teaching practical science online using GIS: a cautionary tale of coping strategies, J Geogr Higher Educ. 2017; 41(3):341-352. https://doi.org/10.1080/03098265.2017.1315531.

Arnaud CH, Flipping chemistry classrooms. Chem. Eng. News. 2013; 91(12):41-43. https://doi.org/10.1021/cen-09112-educ.

Bergmann J, Sams A, Flip your classroom: reach every student in every class every day. Washington, DC: International Society for Technology in Education; 2012.

Binkley C, How U.S. schools are planning for possible spread of coronavirus. 2020 Time. https://time. com/5792377/us-schools-coronavirus-plans/.

Bochner A, Ellis C, Evocative autoethnography: Writing lives and telling stories. New York, NY: Routledge; 2016.

Bransford JD, Donovan MS, Scientific inquiry and how people learn. In: Donovan MS, Bransford JD, editors. How students learn: history, mathematics, and science in the classroom. Washington, D.C.: The National Academies Press; 2005. pp 397-420. https://doi.org/10.17226/10126.

Cavanaugh C, Repetto J, Wayer N, Spitler C, Online learning for students with disabilities: a framework for success. J Special Educ Technol. 2013 Mar; 28(1):1-8. https://doi.org/10.1177/016264341302800101.

CDCP (Center for Disease Control and Prevention). Coronavirus disease 2019 (COVID-19): Stress \& coping. 2020 Retrieved from https://www.cdc.gov/coronavirus/2019-ncov/daily-lifecoping/managing-stress-anxiety.html.

Chandra S, Sharma B, Near, far, wherever you are: chemistry via distance in the south seas. Am J Dist Educ. 2018 Mar; 32(2):80-95, https://doi.org/10.1080/08923647.2018.1440106

Chatham-Carpenter A, The future online: Instructional communication scholars taking the lead. Commun Educ. 2017 Aug; 66(4):492-494. https://doi.org/10.1080/03634523.2017.1349916

CHED (Commission on Higher Education). Memoranda about COVID-19. 2020 https://ched.gov. ph/blog/2020/03/12/guidelines-for-the-prevention-control-and-mitigationof-the-spread- of-the-2019-novel-coronavirus-acute-respiratory-disease-in-higher-educationinstitutions/ 
Childers G, Jones MG, Learning from a distance: high school students' perceptions of virtual presence, motivation, and science identity during a remote microscopy investigation, Int J Sc Educ. 2017 Mar; 39(3):257-273. https://doi.org/10.1080/09500693.2016.1278483

CNN Philippines. Metro Manila air quality improves during quarantine. March 25, 2020 Retrieved from https://www.cnnphilippines.com/news/2020/3/25/metro-manila-improves-air-qualityamid-quarantine.html

Conrad KA, Weber MJ, Social networking in distance learning: planning for Ssuccess. The Academic Forum Conference Proceedings. 2015 (p. 1).

Curtis H, Werth L, Fostering student success and engagement in a $\mathrm{K}-12$ online school. J Online Learning Res. 2015 Aug; 1(2):163-190. https://www.learntechlib.org/primary/p/150962/

Darling-Hammond L, Hyler ME, Gardner M, Effective teacher professional development. Palo Alto, CA: Learning Policy Institute; 2017.

Davenport JL, Rafferty AN, Yaron DJ. Whether and how authentic contexts using virtual chemistry lab support learning. J Chem Educ. 2018 Jul; 95(8):1250-1259. https://doi.org/10.1021/acs.jchemed.8b00048.

DepEd (Department of Education). Memoranda about COVID-19. 2020 https://www.deped.gov.ph/ covid-19/covid19-memoranda/

DOH (Department of Health) COVID-19 Bulletin No. 67. Available from https://www.doh.gov.ph/ accessed on May 21, 2020.

Doka, KJ, Walter, T. Death in the modern world. Omega J Death Dying. 2020 Mar; https://doi.org/10.1177/0030222820914430.

Domagoso IM, Breaking News: Isko Moreno Domagoso from the Manila Public Information Office. 2020 http://www.facebook.com/iskomorenodomagoso/videos/825532404598731/

Doucet A, Netolicky D, Timmers K, Tuscano FJ, Thinking about pedagogy in an unfolding pandemic: an independent report on approaches to distance learning during COVID-19 school closures. 2020. https://creativecommons.org/licenses/by-nc-sa/4.0/

Driver H, How to alleviate loneliness when you study online. Online Learning Tips. 2018 https://onlinelearningtips.com/2018/12/alleviate-loneliness/

Dunlap JC, Lowenthal PR, The power of presence: our quest for the right mix of social presence in online courses. In Mizell AP, Piña AA editors, Real life distance education: case studies in practice. Charlotte, NC: Information Age Publishing; 2014.

Eckert B, Grober S, Jodl HJ, Distance education in physics via the internet. Amer J Distance Educ. 2009 Aug; 23(3):125-138. https://doi.org/10.1080/08923640903076735

Farrell TSC, Promoting teacher reflection in second language education: a framework for TESOL professionals. London: Routledge; 2015. 
Faulconer EK, Griffith JC, Wood BL, Acharyya S, Roberts DL, A comparison of online and traditional chemistry lecture and lab, Chem. Educ. Res. Pract. 2018 19(1), 392-397. https://doi.org/10.1039/C7RP00173H

Fautch JM, The flipped classroom for teaching organic chemistry in small classes: is it effective? Chem Educ Res Pract. 2015 Jan; 16:179-186. https://doi.org/10.1039/C4RP00230J

Favale T, Soro F, Trevisan M, Drago I, Melia M, Campus traffic and e-Learning during COVID19 pandemic. Computer Networks. 2020 Jul; 176:107290. https://doi.org/10.1016/j.comnet.2020.107290.

Finn AN, Schrodt P, Students' perceived understanding mediates the effects of teacher clarity and nonverbal immediacy on learner empowerment. Communication Education. 2012 Feb; 61(2):111130. https://doi.org/10.1080/03634523.2012.656669.

Fishman B, Fischer C, Kook JF, Levy A, Jia Y, Eisenkraft A, ... McCoy A, Professional development for the redesigned AP biology exam: Teacher participation patterns and student outcomes. Paper presented at the American Education Research Association Annual Meeting, Philadelphia, PA; 2014.

FITED (Foundation for Information Technology Education and Development) Inc. under a Creative Commons Attribution 4.0 International License. 2020: https://creativecommons.org/licenses/by/4.0/.

Frumin K, Dede C, Fischer C, Foster B, Lawrenz F, Eisenkraft A, Fishman B, Levy AJ, McCoy A, Adapting to large-scale changes in advanced placement biology, chemistry, and physics: the impact of online teacher communities. Int J Sci Educ. 2018 Jan; 40(4):397-420. https://doi.org/10.1080/09500693.2018.1424962.

Galloway KR, Stoyanovich C, Flynn AB, Students' interpretations of mechanistic language in organic chemistry before learning reactions. Chem Educ Res Pract. 2017 Feb; 18:353- 374 . https://doi.org/10.1039/C6RP00231E.

Garrison DR, Anderson T, Archer W, Critical inquiry in a text-based environment: computer conferencing in higher education. The Internet and Higher Education. 2000 2(2-3):87-105. https://doi.org/10.1016/S1096-7516(00)00016-6.

Gemin B, Pape L, Keeping pace with K-12 digital learning: an annual review of policy and practice. Evergreen, CO: Evergreen Education Group; 2016.

Gill MG, Trevors G, Greene JA, Algina J, Don't take it personally? The role of personal relevance in conceptual change. J Exp Educ. 2020 Apr; 1-22 https://doi.org/10.1080/00220973.2020.1754152.

Goldschmidt K, The COVID-19 pandemic: Technology use to support the wellbeing of children. Journal of Pediatric Nursing. 2020 In Press. https://doi.org/10.1016/i.pedn.2020.04.013.

Guernsey L, Ishmael K, Prescott S, Online learning in the wake of COVID-19 tips and resources for PreK-12 with equity in mind, New America. 2020 https://www.newamerica.org/educationpolicy/edcentral/online-lea rning-wake-covid-19/.

Gulacar O, Damkaci F, Bowman C, A comparative study of an online and a face-to-face chemistry course. J Interact Online Learn. 2013 12(1):27-40. 


\section{Teaching Junior High School Chemistry During the COVID-19 Community...}

Hayler M, Autoethnography, self-narrative and teacher education. Rotterdam: Sense publishers; 2011.

Hodges C, Moore S, Lockee B, Trust T, Bond A, The difference between emergency remote teaching and online teaching. 2020 Retrieved from https://er.educause.edu/articles/2020/3/thedifference-between-emergency-remote-teaching-and- online-learning

ISTE (International Society for Technology in Education). Better edtech buying for educators. Arlington, VA: International Society for Technology in Education; 2019.

Kaufmann R, Buckner MM, Revisiting "power in the classroom": exploring online learning and motivation to study course content. Interact Learn Environ. 2019; 27(3):402-409. https://doi.org/10.1080/10494820.2018.1481104.

Kaufmann R, Vallade JI, Exploring connections in the online learning environment: student perceptions of rapport, climate, and loneliness. Interact Learn Environ. 2020 Apr; In Press. https://doi.org/10.1080/10494820.2020.1749670.

Kaufmann R, Frisby BN, Dimensions of instructor disclosure: implications for rhetorical and relational goals of instruction. Commun Res Rep. 2017 Mar; 34(3):221-229. https://doi.org/10.1080/08824096.2017.1286469.

Koedinger KR, Aleven V, An interview reflection on "intelligent tutoring goes to school in the big city”. Int J Artif Intell Educ. 2016 Mar; 26(1):13-24. https://doi.org/10.1007/s40593-015-0082-8.

Kong SC, Parents' perceptions of e-learning in school education: implications for the partnership between schools and parents. Tech Pedagog Educ. 2018; 27(1):15-31. https://doi.org/10.1080/1475939X.2017.1317659.

Kumi-Yeboah A, Dogbey J, Yuan G, Exploring factors that promote online learning experiences and academic self-concept of minority high school students. J Res Technol Educ. 2018; 50(1):117. https://doi.org/10.1080/15391523.2017.1365669.

Lansangan RV, Orleans AV, Camacho VI, Assessing conceptual understanding in chemistry using representation. Adv Sci Lett. 2018 Nov; 24(11):7930-7934. https://doi.org/10.1166/asl.2018.12459.

Lopez V, Code Red Sub-Level 2: Duterte announces community quarantine vs. COVID-19. Retrieved from GMA News Online. 2020 https://www.gmanetwork.com/news/news/nation/729459/code-red-sub-level-2-duterteannounces-tougher-measures-vs-covid-19-threat/story

Markic S, Childs PE, Language and the teaching and learning of chemistry. Chem Educ Res Pract. 2016 Jun; 17(3):434-438. https://doi.org/10.1039/C6RP90006B.

McCollum B, Morsh L, Shokoples B, Skagen D, Overcoming barriers for implementing international online collaborative assignments in chemistry. The Canadian Journal for the Scholarship of Teaching and Learning. 2019 May; 10(1). https://doi.org/10.5206/cjsotlrcacea.2019.1.8004.

Means B, Toyama Y, Murphy R, Bakia M, Jones K, Evaluation of evidence-based practices in online learning: a meta-analysis and review of online learning studies, Washington, D.C.: U.S. Department of Education; 2010. 
Murphy MPA, COVID-19 and emergency eLearning: Consequences of the securitization of higher education for post-pandemic pedagogy. Contemp Secur Policy. 2020 Apr; In Press. https://doi.org/10.1080/13523260.2020.1761749.

Miller ED, The COVID-19 pandemic crisis: the loss and trauma event of our time. J Loss Trauma. 2020 Apr; In press. https://doi.org/10.1080/15325024.2020.1759217.

Miller ED, The academic psychologist as a convener of information: Implications for the scholarship of integration and (online) teaching. New Ideas Psychol. 2014 Apr; 33:35-45. https://doi.org/10.1016/j.newideapsych.2014.01.001.

Moorhouse BL, Adaptations to a face-to-face initial teacher education course "forced" online due to the COVID-19 pandemic. J Educ Teach. 2020 Apr; In press. https://doi.org/10.1080/02607476.2020.1755205.

Morgan, H. Online instruction and virtual schools for middle and high school students: Twentyfirst-century fads or progressive teaching methods for today's pupils? The Clearing House. 2015 Apr; 88(2):72-76. https://doi.org/10.1080/00098655.2015.1007909.

Mottet TP, Frymier AB, Beebe SA, Theorizing about instructional communication. In Mottet TP, Richmond VP, McCroskey JC (Eds.), Handbook of instructional communication: Rhetorical and relational perspectives. Allyn \& Bacon; 2006. p. 255-282.

Munyofu M, Swain WJ, Ausman BD, Lin H, Kidwai K, Dwyer F, The effect of different chunking strategies in complementing animated instruction. Learn Media Technol. 2007 Nov; 32(4):407419. https://doi.org/10.1080/17439880701690109.

Myers SA, Goodboy AK, Members of COMM 600. College student learning, motivation, and satisfaction as a function of effective instructor communication. South Commun J. 2014 Mar; 79(1):14-26. https://doi.org/10.1080/1041794X.2013.815266

Nennig HT, Idarraga KL, Salzer LD, Bleske-Rechek A, Theisen RM, Comparison of student attitudes and performance in an online and a face-to-face inorganic chemistry course. Chem Educ Res Prac. 2020; 21:168-177. https://doi.org/10.1039/C9RP00112C.

Ngu BH, Phan HP, Comparing balance and inverse methods on learning conceptual and procedural knowledge in equation solving: a cognitive load perspective. Pedagog Int J. 2016; 11(1):63-83. https://doi.org/10.1080/1554480X.2015.1047836.

Nicomedes CJ, Avila RM, Arpia HM, The lived experiences of Filipino front liners during COVID-19 outbreak. 2020

https://www.researchgate.net/publication/340444633_The_Lived_Experiences_of_Filipino_Fr ont_Liners_During_COVID-19_Outbreak

Peachey N, Synchronous Online Teaching. In: Carrier M, Damerow RM, Bailey KM, (Eds). Digital Language Learning and Teaching. New York, NY: Routledge; 2017. p 143-155.

Reedy AK, Rethinking online learning design to enhance the experiences of indigenous higher education stu- dents. Australas J Educ Technol. 2019; 35(6):132-149. https://doi.org/10.14742/ajet.5561.

Rice K, Making the move to K--12 online teaching: Research-based strategies and practices. Saddle River, NJ:Pearson Education; 2012. 
Rodriguez MKT, UST-JHS technology and connectivity survey. 2020 Retrieved from https://docs.google.com/forms/d/1iDltLE3UjF3GvMF7KQIPO-88IREeYiMGIMZcJYBIrk/edit

Sadulski J, Transition to online learning challenges K-12 students and teachers. 2020 Retrieved from https://onlinelearningtips.com/2020/05/transition-online-learning-k-12-studentsteachers/

Sandhu P, de Wolf M, The impact of COVID-19 on the undergraduate medical curriculum, Med Educ Online. 2020 May; 25(1):1764740. https://doi.org/10.1080/10872981.2020.1764740.

Shearer RL, Aldemir T, Hitchcock J, Resig J, Driver J, Kohler M, What Students Want: a vision of a future online learning experience grounded in distance education theory. Amer J Distance Educ. 2020; 34(1):36-52. https://doi.org/10.1080/08923647.2019.1706019.

Seery M, Donnelly R, The implementation of pre-lecture resources to reduce in-class cognitive load: A case study for higher education chemistry. Br J Educ Technol. 2012 Jul; 43(4):667-677. https://doi.org/10.1111/j.1467-8535.2011.01237.x.

Speedtest Global Index. Philipines April 2020. https://www.speedtest.net/globalindex/philippines\#mobile

Spitler C, Transition compliance and evidence-based practices in public cyber charter-schools: Effects of student demographics (Doctoral dissertation, University of Florida, Gainseville, FL). 2013, Retrieved from ProQuest Disser- tations and Theses database. (UMI No. 583588).

Talidong KJB, Toquero CMD, Philippine teachers' practices to deal with anxiety amid COVID19. J Loss Trauma. 2020 May; In Press. https://doi.org/10.1080/15325024.2020.1759225.

Taskin V, Bernholt S, Students' understanding of chemical formulae: a review of empirical research. Int J Sci Educ. 2014; 36(1):157-185. https://doi.org/10.1080/09500693.2012.744492.

UNESCO (United Nations Educational, Scientific and Cultural Organization). COVID-19 Educational Disruption and Response. 2020 https://en.unesco.org/covid19/educationresponse

UST (University of Santo Tomas) Advisory. Facebook Page. March 20, 2020. Retrieved from https://www.facebook.com/ustjuniorhighschool/

UST Edtech (University of Santo Tomas Educational Technology) Center Facebook Page. March 9, 2020 post on [insert title of post]. Retrieved from https://www.facebook.com/ustedtechcenter/

UST (University of Santo Tomas) Website News and Events. DPP school officials gather in UST for possible digital learning collaboration. March 6, 2020. Retrieved from http://www.ust.edu.ph/uwide-news/dpp-school-officials-gather-in-ust-for-possible-digitallearning-collaboration/

Visser R, Flynn AB, What are students' learning and experiences in an online learning tool designed for cognitive and metacognitive skill development? Collect Essays on Learning and Teaching. 2018; 11:129-140. https://eric.ed.gov/?id=EJ1182852

Walsh S, Mann S, Doing reflective practice: a data-led way forward. ELT Journal. 2015 Oct; 69 (4):351-362. https://doi.org/10.1093/elt/ccv018. 
Weaver GC, Green K, Rahman A, Epp E, An investigation of online and face-to-face communication in general chemistry. Int J Scholarsh Teach Learn. 2009; 3(1):18. https://doi.org/10.20429/ijsotl.2009.030118.

Wiederhold BK, Using social media to our advantage: Alleviating anxiety during a pandemic. Cyberpsychol Behav Soc Netw. 2020 Apr; 23(4):197-198. https://doi.org/10.1089/cyber.2020.29180.bkw.

Wilder-Smith A, Freedman DO, Isolation, quarantine, social distancing and community containment: Pivotal role for old-style public health measures in the novel coronavirus (2019nCoV) outbreak. J Travel Med. 2020 Mar; 27(2):1-4. https://doi. org/10.1093/jtm/taaa020

Yung KW, Becoming a teacher educator through being a student teacher: an autoethnography in the practicum. J Educ Teach. 2020 Mar; 46(2):248-250. https://doi.org/10.1080/02607476.2020.1724655. 